\title{
Screening and identification of B cell epitope of the nucleocapsid protein in SARS-CoV-2 using the monoclonal antibodies
}

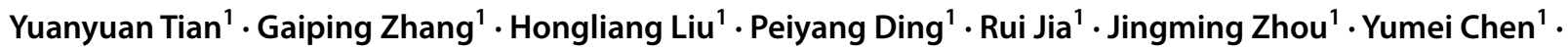 \\ Yanhua $\mathrm{Qi}^{1}$ · Jinran $\mathrm{Du}^{1} \cdot$ Chao Liang ${ }^{1} \cdot$ Xifang Zhu ${ }^{1} \cdot$ Aiping Wang ${ }^{1}$ (I)
}

Received: 3 September 2021 / Revised: 10 December 2021 / Accepted: 7 January 2022 / Published online: 17 January 2022

(c) The Author(s), under exclusive licence to Springer-Verlag GmbH Germany, part of Springer Nature 2022

\begin{abstract}
Severe acute respiratory syndrome coronavirus 2 (SARS-CoV-2) is the virus that causes the coronavirus disease (COVID-19). It is confirmed that nucleocapsid $(\mathrm{N})$ protein is closely related to viral pathogenesis, modulation of host immune response, RNA transcription, and replication and virus packaging. Therefore, the $\mathrm{N}$ protein is a preponderant antigen target for virus detection. The codon-optimized $\mathrm{N}$ gene was designed according to the encoding characteristics of insect cells and inserted into $\mathrm{pFastBac}{ }^{\mathrm{TM}} 1$ vector with $6 \times$ His-tag-fused $\mathrm{N}$ protein for expression in insect sf 21 cells. Six anti-N mAbs $(4 \mathrm{G} 3,5 \mathrm{~B} 3$, 12B6, 18C7-A2, 21H10-A3, 21H10-E9) were prepared by recombinant $\mathrm{N}$ protein. The mAbs showed high titers, antibody affinity, and reactivity with the SARS-CoV-2 N protein. Then, fourteen overlapped peptides that covered the intact $\mathrm{N}$ protein were synthesized (N1-N14). Peptide N14 was identified as the main linear B-cell epitope region via peptide-ELISA and dot-blot assay, and this region was truncated gradually until mapping the peptide 401-DFSKQLQQ-408. Simultaneously, compared with the sequence of variants of concern (VOCs) and variants of interest (VOIs) strains among the several countries, epitope 401-DFSKQLQQ-408 is very conservative among them. The findings provide new guidance for the design and detection of COVID-19 targets.
\end{abstract}

\section{Key points}

- The $N$ protein was optimized according to the insect cell codon preference and was highly expressed.

- The monoclonal antibodies prepared in this study were shown high antibody titers and high affinity.

- Monoclonal antibodies were used to map the epitope 401-408 amino acids of N protein for the first time in this study.

Keywords SARS-CoV-2 $\cdot$ Nucleocapsid protein $\cdot$ Monoclonal antibodies $\cdot$ B-cell epitope

\section{Introduction}

A novel type of coronavirus caused a pneumonia large area outbreak and epidemic around the world (Zhu et al. 2020b; Wu et al. 2020a). According to research, the virus has a strong capacity to spread from person to person (Chan et al. 2020). On January 12, 2020, the novel pneumonia was named 2019-nCoV (later renamed COVID-19) by the World Health Organization (Gorbalenya et al. 2020). Sequencing the genome of the virus that generated COVID-19 showed

Aiping Wang

pingaw@126.com

1 School of Life Sciences, Zhengzhou University, No. 100 Science Avenue, Zhengzhou 450001, People's Republic of China that it is related to SARS-CoV that caused the outbreak in 2002. On February 11, based on its phylogenetic similarity to SARS-CoV (de Groot et al. 2012), the new coronavirus was named SARS-CoV-2. The clinical manifestations of patients with COVID-19 are mainly fever, malaise, fatigue, soreness, dry cough, and even chest tightness, dyspnea (Huang et al. 2020a). The virus has a very high transmission and infection rate in the pre-symptomatic phase. The COVID-19 constitutes global public health security and a great threat (Liu et al. 2020; Hu et al. 2020).

SARS-CoV-2 is a kind of enveloped coronavirus with round virus particles and coronal arrangement of fibrils around it, which are distributed in the cytoplasm, positive single-stranded RNA virus with a genome length of approximately $30 \mathrm{~kb}$ (Huang et al. 2020b). There is a methylated cap structure at the 5 'end and a poly-A tail structure at the 3 'end 
of the virus genome; the coding region contains the open reading frame (ORF) and other auxiliary genes common to coronaviruses. The ORF encodes viral structural proteins mainly including spike $(\mathrm{S})$ protein, nucleocapsid $(\mathrm{N})$ protein, envelope (E) protein and membrane (M) protein (Zhou et al. 2020). Among them, N protein is a phosphoprotein and composed of 418 amino acid residues, located in the nucleus. The $\mathrm{N}$ protein mainly contains two globular domains, the $\mathrm{N}$ - and C-terminal domains (NTD and CTD, respectively), surrounded by intrinsically disordered regions. $\mathrm{N}$ protein is highly basic (pI 10), and multiple RNA-binding sites are found throughout the protein (Kang et al. 2020). The NTD is an RNA-binding domain. The CTD forms a tightly linked dimer with a large RNA-binding groove. The nucleocapsid is the most abundant protein in coronaviruses and its amino acid sequence is largely conserved as previously reported (Tilocca et al. 2020). Despite it being located within the viral particle rather than on its surface, patients infected with SARS-CoV-2 showed higher and earlier antibody responses to the nucleocapsid protein than to the surface spike protein (Burbelo, et al. 2020). Previous studies had reported on SARS-CoV N protein epitopes as capable of eliciting massive production of antibodies in infected subjects (Tilocca et al. 2020). Similar to the function of SARS-CoV, the N protein acts a pivotal part in the pathogenesis. For example, it can form nucleocapsid with viral genome RNA (Zhu et al. 2020a; Snijder et al. 2003), participate in viral genome replication and particle assembly, may bind to host SMcAD3 and regulate transforming growth factor-beta signaling (Stertz et al. 2006), and has strong immunogenicity, which can induce the body to produce a high level of immune response (Zhao et al. 2008). N protein is highly conserved and strong antigenic in CoVs; $89 \%$ of the SARS patients induced the antigen-antibody. On the other hand, other studies have shown that the $\mathrm{N}$ protein immunization did not lead to the production of neutralizing antibodies; in essence, however, due to its strong immunogenicity, $\mathrm{N}$ protein can be used as a diagnostic test target protein. S protein is a key protein that mediates virus invasion into target cells and induces the production of antiviral neutralizing antibodies. $\mathrm{S}$ protein was cleaved into S1 and S2 parts. However, S1 is highly variable, and there are significant differences among different viruses or different strains of the same virus. Furthermore, in comparison with other structural proteins, $\mathrm{N}$ protein has the highest expression content among the structural proteins during the infection and it can be highly detected in infected patients (Wu et al. 2004a; Zhang et al. 2011), which make it to be an antigen for diagnostic antibody (Egger et al. 2020). Therefore, both $\mathrm{N}$ protein and antibodies against it are all important detection targets for SARS-CoV-2 infection.

Epitopes are the basis of protein antigenicity. Accurate and detailed mapping of the epitopes of protein is very important for the diagnosis and prognosis of diseases, the design of vaccine molecular structure, and immune intervention therapy ( $\mathrm{Li}$ et al. 2003). According to the characteristics of B cell epitopes, it is an easy application and economical method to predict antigen epitopes in advance, and then to synthesize peptides and verify them in experiments (Luo et al. 2015). Among them, spikes protein has several mutation hotspots, while nucleocapsid protein is more stable (Chen et al. 2020a). The study of epitopes is of great significance in basic etiology, immunology, pharmacology, and preventive medicine, as well as a clinical diagnosis.

\section{Materials and methods}

\section{Gene, cells, and animals}

Based on the original SARS-CoV-2, N protein sequence (GenBank accession No. QOQ37303.1) was acquired from the NCBI, the design was greatly improved, and the codonoptimized $\mathrm{N}$ protein gene was designed according to the encoding characteristics of insect cells (Figure S1). The eukaryotic expression vector was $\mathrm{pFastBac}^{\mathrm{TM}} 1$, the restriction enzyme cutting sites were $B a m H \mathrm{I}$ and $X b a \mathrm{I}$, and the recombinant plasmid was synthesized by Sangon Biotech (Shanghai) Co., Ltd. (China). The sequence of SARS-CoV N (GenBank accession No. NP_828858.1) and MERS-CoV $\mathrm{N}$ (GenBank accession No. ATG84884.1) protein were also expressed in insect cells. The competent cell Escherichia coli DH10Bac and competent cell Escherichia coli DH5 $\alpha$ were purchased from Beijing Biomed Genomics Central Co., Ltd. (China). The myeloma SP2/0 and sf21 insect cells were stored in our laboratory. Human embryonic kidney $293 \mathrm{~T}$ (HEK293T) cells were obtained from ATCC (Manassas, VA, USA). BALB/c mice were purchased from Henan Sikebesi Biological Technology Co. LTD (Henan, China).

\section{Construction and expression of $\mathbf{N}$ protein}

The recombinant plasmid of $\mathrm{N}$ protein was designed with secretory expression signal peptide and C-terminal $6 \times$ His label. The plasmid was transformed into Escherichia coli DH10Bac competent cell and positive clones that are recombinant Bacmid were obtained by blue-white screening. The recombinant baculovirus stock was obtained from sf21 cell culture supernatant after transfection $72 \mathrm{~h}$, then infection sf21 cells with the harvested recombinant baculovirus stock again up to three cycles. Then amplify the baculoviral stock and protein expression. The cell supernatant in culture was collected and bound into Ni Sepharose ${ }^{\mathrm{TM}}$ excel affinity column (His Trap TM excel, GE). Following washed with gradient washing buffers ( $25 \mathrm{mM}$ Tris- $\mathrm{HCl} \mathrm{pH} 8.0,50 \mathrm{mM} \mathrm{NaCl}$, 10,20 , and $50 \mathrm{mM}$ Imidazole). The $\mathrm{N}$ protein was eluted with elution buffer ( $25 \mathrm{mM}$ Tris- $\mathrm{HCl} \mathrm{pH} 8.0,50 \mathrm{mM} \mathrm{NaCl}$, 
$200 \mathrm{mM}$ Imidazole). The N protein was also expressed in the prokaryotic system (Escherichia coli BL21 (DE3) cells) for follow-up work. The purification method is the same as above.

\section{Animal immunization and hybridoma cell production}

Five female BALB/c mice were immunized with $\mathrm{N}$ protein expressed in sf 21 cells. The immunization strategy is subcutaneous multipoint injection with purified $\mathrm{N}$ protein. The immunization dose is a $200 \mu \mathrm{L}$ emulsion containing $4.5 \mu \mathrm{g}$ antigen mixed with Freund's complete adjuvant. Three booster immunizations were given at the same dose at every 3-week interval. Blood samples were collected for antibody titer determination. The mouse with the highest titer was given the last booster immunization intraperitoneally. Then it was euthanized through carbon dioxide $\left(\mathrm{CO}_{2}\right)$ inhalation. The spleen cells were fused with SP2/0 that cells are round, transparent and grow exponentially, more adherent and less suspended using the PEG-1500 (Sigma-Aldrich, USA). The fused cells were resuspended in a HAT selection medium containing 10\% Fetal Bovine Serum (Sigma-Aldrich, USA) and transferred into 96-well culture plates and grew in a specified incubator (Thermo Fisher Scientific, USA) with $5 \% \mathrm{CO}_{2}$ at $37^{\circ} \mathrm{C}$. After cell fusion $7-10$ days, the positive hybridomas were screened by indirect ELISA. In the middle, HT medium was used to replace HAT medium to continue screening positive hybridoma cells. Positive hybridoma cells were sub-cloned two to three cycles via the finite dilution method (Oliveria et al. 2020; Li et al. 2013).

\section{Preparation and characterization of monoclonal antibodies}

All antibodies were prepared from ascites in mice. To be specific, Freund's incomplete adjuvant was injected into the abdominal cavity of old BALB/c mice (500 uL per mouse) when one week before injection of hybridoma culture suspensions $\left(1 \times 10^{6}\right.$ hybridoma cells). Seven days after hybridoma injection, ascites were collected, then purification by $\mathrm{N}$-octanoic acid and saturated ammonium sulfate precipitation, successively. The SDS-PAGE was used to analyze the purified $\mathrm{N}$ mAbs. We identified the isotype of mAbs of the screened by the Mouse Monoclonal antibody Subtype Identification Kit (Proteintech, USA). Mouse monoclonal antibody-specific subtypes include heavy chain (IgG1, IgG2a, $\operatorname{IgG} 2 b, \operatorname{IgG} 2 \mathrm{c}, \operatorname{IgG} 3$, and $\operatorname{IgM}$ ) and light chain (Kappa and Lambda), the operation was carried out according to the manufacture's instruction (Wang et al. 2020b).

\section{Indirect ELISA and western blot}

The titer of monoclonal antibodies and screening of positive clonal hybridoma cell lines were determined by indirect ELISA. The $\mathrm{N}$ protein as coating antigen that was coated on 96-well plates diluted to $1 \mu \mathrm{g} / \mathrm{mL}$ with carbonate buffer (0.05 M sodium carbonate-sodium bicarbonate, $\mathrm{pH}$ 9.6) incubated at $4{ }^{\circ} \mathrm{C}$ overnight. The coated plates were washed by PBST $(1 \times$ PBS with $0.05 \%$ Tween 20 , pH 7.4$)$ for $3-4$ times and were blocked with $5 \%$ skimmed milk at $37{ }^{\circ} \mathrm{C}$ for $1 \mathrm{~h}$. Primary antibody (immunized mice serum or culture medium of $\mathrm{N}$ monoclonal antibody-contained or different dilutions of purified $\mathrm{N}$ monoclonal antibodies) were incubated at $37{ }^{\circ} \mathrm{C}$ for $30 \mathrm{~min}$ and the HRP-conjugated Affinipure Goat Anti-Mouse $\operatorname{IgG}(\mathrm{H}+\mathrm{L}$ ) (Proteintech, USA, Cat No. SA00001-1) were as the secondary antibody incubated at $37^{\circ} \mathrm{C}$ for $30 \mathrm{~min}$. After washing the plates, the reaction was stopped by a stop solution ( $2 \mathrm{~mol} / \mathrm{L} \mathrm{H}_{2} \mathrm{SO}_{4}$ ). The optical density (OD) values were determined at $450 \mathrm{~nm}$ via a microplate reader.

The specificity of mAbs against the $\mathrm{N}$-His fusion protein and the expression of $\mathrm{N}$-His fusion protein were verified by western blot. The $\mathrm{N}$ protein was performed by SDS-PAGE and the protein gel was transferred onto a PVDF membrane with tris-glycine transfer buffer (39 mM glycine, $48 \mathrm{mM}$ tris, $1.28 \mathrm{mM}$ SDS, 20\% methanol), blocked (PBST with $0.5 \%$ skimmed milk), and then incubated with HRP conjugated 6*His-Tag Monoclonal Antibody (Proteintech, USA, Cat No. HRP-66005) or mouse anti-N monoclonal antibodies antiserum at room temperature for $1 \mathrm{~h}$. The Goat anti-Mouse poly-HRP antibody (Proteintech, USA, Cat No. SA00001-1) was used as the secondary antibody. After, the PVDF membrane was washed, mixed with ECL chemiluminescence reagents, and then imaged on a chemiluminescence imaging system instrument.

\section{Peptide design and synthesis}

A total of 419 amino acids in the full length of $\mathrm{N}$ protein were segmented and truncated into 14 peptides, of which the first 13 peptides each contained 35 amino acid residues, and the last one contained 41 amino acid residues; 5 amino acid residues were overlapped between two adjacent peptides (Table 1). A cysteine was added to the $\mathrm{N}$-terminal of each peptide for subsequent peptide coupling. The peptides were synthesized by GL Biochem (Shanghai, China) Ltd., and peptides were purified via high-performance liquid chromatography with higher than $95 \%$ purity.

\section{Peptide ELISA and dot-blot assay}

The peptides were conjugated to the BSA protein by coupling reagent Sulfo-SMCC (Thermo Scientific, USA). 
Table 1 Amino acid sequences of 14 overlapped synthetic peptides of SARS-CoV-2 N protein (Five amino acid residues are repeated between adjacent peptides)

\begin{tabular}{lll}
\hline Peptide ID & Sequence & Location \\
\hline N1 & SDNGPQNQRNAPRITFGGPSDSTGSNQNGERSGAR & 1-35aa \\
N2 & ERSGARSKQRRPQGLPNNTASWFTALTQHGKEDLK & $30-64 a \mathrm{a}$ \\
N3 & GKEDLKFPRGQGVPINTNSSPDDQIGYYRRATRRI & 59-93aa \\
N4 & RATRRIRGGDGKMKDLSPRWYFYYLGTGPEAGLPY & $88-122 \mathrm{aa}$ \\
N5 & EAGLPYGANKDGIIWVATEGALNTPKDHIGTRNPA & $117-151 \mathrm{aa}$ \\
N6 & GTRNPANNAAIVLQLPQGTTLPKGFYAEGSRGGSQ & $146-180 \mathrm{aa}$ \\
N7 & SRGGSQASSRSSSRSRNSSRNSTPGSSRGTSPARM & $175-209 \mathrm{aa}$ \\
N8 & TSPARMAGNGGDAALALLLLDRLNQLESKMSGKGQ & $204-238 \mathrm{aa}$ \\
N9 & MSGKGQQQQGQTVTKKSAAEASKKPRQKRTATKAY & $233-267 \mathrm{aa}$ \\
N10 & TATKAYNVTQAFGRRGPEQTQGNFGDQELIRQGTD & $262-296 \mathrm{aa}$ \\
N11 & IRQGTDYKHWPQIAQFAPSASAFFGMSRIGMEVTP & $291-325 \mathrm{aa}$ \\
N12 & GMEVTPSGTWLTYTGAIKLDDKDPNFKDQVILLNK & $320-354 \mathrm{aa}$ \\
N13 & VILLNKHIDAYKTFPPTEPKKDKKKKADETQALPQ & $349-383 \mathrm{aa}$ \\
N14 & TQALPQRQKKQQTVTLLPAADLDDFSKQLQQSMSSADSTQA & $378-418 \mathrm{aa}$ \\
\hline
\end{tabular}

Specifically, dissolved Sulfo-SMCC in DMSO and added $\mathrm{BSA}$, then stirred at RT for $1 \mathrm{~h}$ wherein BSA was dissolved in coupling buffer, including $0.1 \mathrm{M} \mathrm{PB}, \mathrm{pH} 7.2,0.15 \mathrm{M}$ $\mathrm{NaCl}$, and $1 \mathrm{mM}$ EDTA. The excess coupling reagent was removed via dialysis. Finally, the peptides and the SulfoSMCC-BSA were mixed overnight at $4^{\circ} \mathrm{C}$. The conjugated peptides were coated as antigen, and the operation method was the same as indirect ELISA.

The coupled peptides were dropped onto the nitrocellulose filter (NC) membrane which was completely wetted with $1 \times$ PBS and then dried. Then blocked at $37^{\circ} \mathrm{C}$ for $2 \mathrm{~h}$ using 5\% skimmed milk and incubated with the mouse anti$\mathrm{N}$ monoclonal antibodies antiserum at indoor temperature for $1 \mathrm{~h}$. The follow-up operation method was the same as western blot.

\section{Immunofluorescence assay}

The specificity of the $\mathrm{N}$ protein with screened anti-N mAbs was determined by immunofluorescence assay. The HEK293T cells were cultured in a 12-well cell plate and the cell density reached 70-80\%; the constructed positive plasmid pcDNA3.1-N was transfected with Lipofectamine®2000 (Invitrogen, Life Technologies, USA). Thirty-six to $48 \mathrm{~h}$ after transfection, the cells were fixed with methanol at -20 ${ }^{\circ} \mathrm{C}$ for 5-10 min, washed with PBST three times, then blocked at $37{ }^{\circ} \mathrm{C}$ for $1-2 \mathrm{~h}$ using $5 \%$ skimmed milk. The $\mathrm{N}$ monoclonal antibodies were as the primary antibody incubated at RT for $1 \mathrm{~h}$. The secondary antibody was the Donkey anti-Mouse IgG $(\mathrm{H}+\mathrm{L})$ Highly Cross-Adsorbed Secondary Antibody, Alexa Fluor 488 (Invitrogen, Life Technologies, USA, Cat No.A-21202) incubated at RT for $1 \mathrm{~h}$, then the cells were stained by $4^{\prime} 6$-diamidine-2-phenylindole dihydrochloride (DAPI, SolarBio, China) and observed under a fluorescence microscope (ZEISS, Germany) (Xie et al. 2018; Jiang et al. 2020).

\section{Structure prediction}

SWISS-MODEL was used to construct the spatial structure of the SARS-CoV-2 N protein (https://swissmodel. expasy.org/interactive). In this study, the alignment modeling sequence of SARS-CoV-2 N was from 345 to 419 amino acid sequences. The spatial localization of epitope 401-DFSKQLQQ-408 was analyzed and visualized via the PyMOL software (Version 2.5.0).

\section{Statistical analysis}

The image of SDS-PAGE, western blot, dot-blot in this research were performed by the ImageJ (version $1.51 \mathrm{j} 8$ ). The statistical graphics were analyzed using GraphPad Prism 8.0 (version 8.0.1.244). This manuscript was drafted using the Microsoft Office Professional Plus Word 2016. The figures of this study were shown by the Microsoft Office Professional Plus PowerPoint 2016.

\section{Sequence information}

We have submitted the sequence of SARS-CoV $-2 \mathrm{~N}$ protein optimized according to the insect cells codon preference in this study to NCBI. The GenBank accession number is No. MZ948831.1. 
a Rarely Used (0)
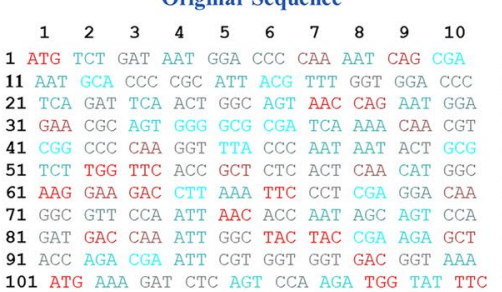

101 ATG AAA GAT CTC AGT CCA AGA TGG TAT TTC

111 TAC TAC CTA GGA ACT GGG CCA GAA GCT GGA

131 ATA TGG GTT GCA ACT GAG GGA GCC TTG AAT

141 ACA CCA AAA GAT CAC ATT GGC ACC CGC AAT
151 CCT GCT AAC AAT GCT GCA ATC GTG CTA CAA
151

151 CCT GCT AAC AAT GCT GCA ATC GTG CTA CAA
161 CTI CCT CAA GGA ACA ACA TTG CCA AAA GGC

171 TTC TAC

181 CAA GCC TCT GA

191 CGC AAC AGT TCA AGA AAT TCA ACT CCA GGC

201 AGC AGT AGG GGA ACT TCT CCT GCT AGA ATG 201

211 GCT GGC AAT GGC GGT GAT GCT GCT CTT GCT 211

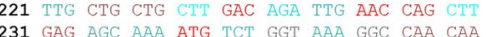

241 CAA CAA GGC CAA ACT GTC ACT AAG AAA TCT 24

251 GCT GCT GAG GCT TCT AAG AAG CCT CGG CAA 251

261 AAA CGT ACT GCC ACT AAA GCA TAC AAT GTA 261

281 CAA ACC CAA GGA AAT TTT GGG GAC CAG GAA

291 CTA ATC AGA CAA GGA ACT GAT TAC AAA CA'

301 TGG CCG CAA ATT GCA CAA TTT GCC CCC AGC

311 GCT TCA GCG TTC TTC GGA ATG TCG CGC ATT 311

321 GGC ATG GAA GTC ACA CCT TCG GGA ACG TGG 321
331 TTG ACC TAC ACA GGT GCC ATC AAA TTG GAT 331
341 GAC

341 GAC AAA GAT CCA AAT TTC AAA GAT CAA GTC
351 ATT TTG CTG AAT AAG CAT ATT GAC GCA TAC
361

361 AAA ACA TTC CCA CCA ACA GAG CCT AAA AAG 360

371 GAC AAA AAG AAG AAG GCT GAT GAA ACT CAA
381 GCC TTA CCG CAG AGA CAG AAG AAA CAG CAA

391 ACT
401 GAT
411

401 GAT GAT TTC TCC AAA CAA TTG CAA CAA TC
411 ATG AGC AGT GCT GAC TCA ACT CAG GCC TA

Fig. 1 Codon optimization of nucleocapsid protein of SARS-CoV-2 a Relative codon frequency distribution of $\mathrm{N}$ protein; Color of codons indicates the frequency for that codon, with respect to the host. Codons that are rarely used are shown in light blue color and fre-

\section{Results}

\section{Expression and purification of $\mathrm{N}$ protein}

A 1260 bp DNA sequence was optimized for $\mathrm{N}$ protein expression preferably in insect sf 21 cells. Codon usage bias was adjusted to fit the better expression profile of the insect. The relative codon frequency distribution was shown in this paper (Fig. 1a). The CAI (Codon Adaptation Index) was upgraded from 0.5 to 0.9 (a CAI of $0.8-1.0$ is regarded as an optimal expression). The content of GC was adjusted from 47.2 to $57.5 \%$ and unfavorable peaks were removed (Fig. 1b). Repeated areas in the original sequences were removed to avoid stem-loop structures in mRNA. The original sequence of the $\mathrm{N}$ protein, the optimized sequence, and amino acid sequence were all shown in this study (Figure $\mathrm{S} 1$ ).

The SARS-CoV-2 N plasmid was transformed into competent cells E. coli DH10 Bac and screened for positive clones and identified by PCR (Figure S2). Then the positive recombinant plasmid was transfected into sf 21 cells to express the recombinant protein. After purification with Ni Sepharose ${ }^{\mathrm{TM}}$ excel affinity column (His Trap ${ }^{\mathrm{TM}}$ excel,

\section{b}
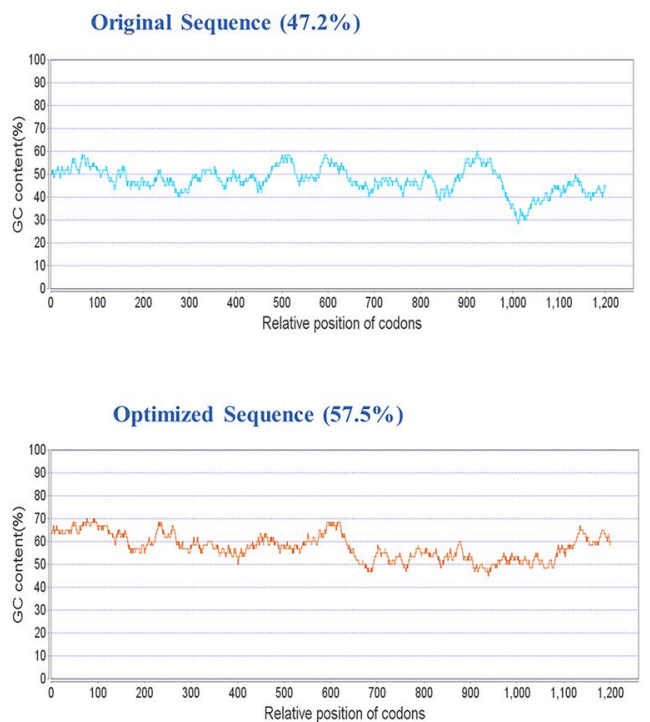

quently used are shown in red color. More red indicates the higher frequency was used and was better suited for the host codon bias, and resulting in higher expression. b GC content adjustment; The original GC content is $47.2 \%$, and the optimized value is $57.5 \%$
GE), the obtained N-His fusion protein was analyzed by SDS-PAGE and western blot. The N-His fusion protein was observed at about $52 \mathrm{kDa}$ (Fig. 2a). The obtained N protein had a purity that can reach $95 \%$, the target protein band in the eluted fraction was recognized at about $52 \mathrm{kDa}$ (Fig. 2b). To further identify the target band, the western blot was performed and the results indicated that a specific distinct band of $\mathrm{N}$-His fusion protein was observed at about $52 \mathrm{kDa}$ (Fig. 2c). Also, SARS-CoV-2 N protein expressed in E. coli strain BL21 (DE3) was observed at about $52 \mathrm{kDa}$ (Fig. 2d). For subsequent experimental studies, SARS-CoV $\mathrm{N}$ and MERS-CoV-N protein were also expressed in insect sf 21 cells, and the results of protein purification were shown in Figure S3.

\section{Mass spectrometric identification of $\mathrm{N}$ protein}

To further prove that the detected protein was the target protein, protein spectrum sequencing was performed. The $\mathrm{N}$ protein was for SDS-PAGE gel electrophoresis, the target gel band (Fig. 2b) was cut off and sent to Shanghai Sangon Biotech Co., Ltd. (China) for protein mass spectrum sequencing. 
Fig. 2 Expression and identification of $\mathrm{N}$ protein a The expression of $\mathrm{N}$ protein was identified by SDS-PAGE.

M: Protein molecular weight standard; 1 : N protein expressed in sf 21 cells. b The expression of $\mathrm{N}$ protein was identified by SDS-PAGE. M: Protein molecular weight standard; $1-2, \mathrm{~N}$ protein expressed in $\mathrm{sf} 21$ cells after purification on Ni-NTA agarose. c Western blot analysis of the $\mathrm{N}$ protein. M: Protein molecular weight standard; $1-2$, western blot for $\mathrm{N}$ protein expressed in sf 21 cells detected using anti-His tag antibody. $\mathbf{d}$ M: molecular-weight markers;

1, The expression of $\mathrm{N}$ protein in E. coli BL21 (DE3).

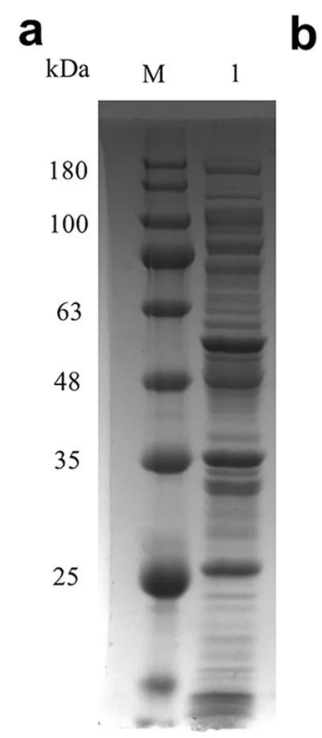

d

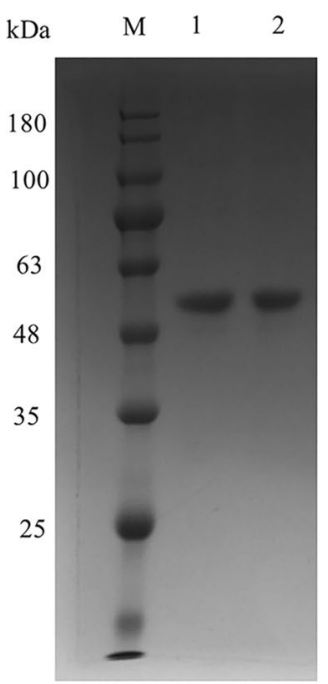

C

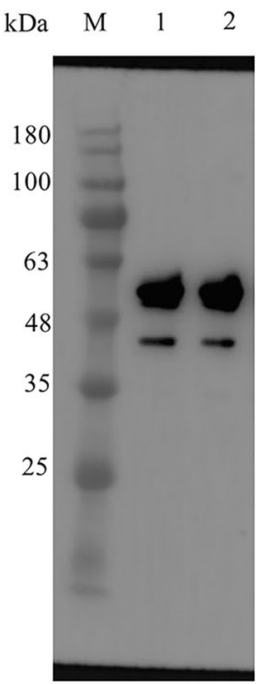

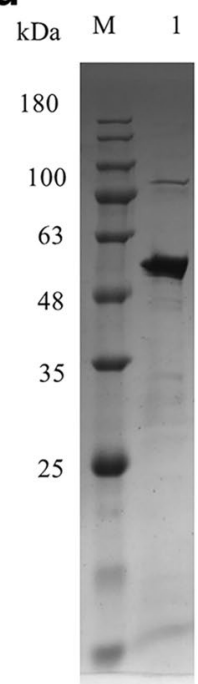

\section{a}

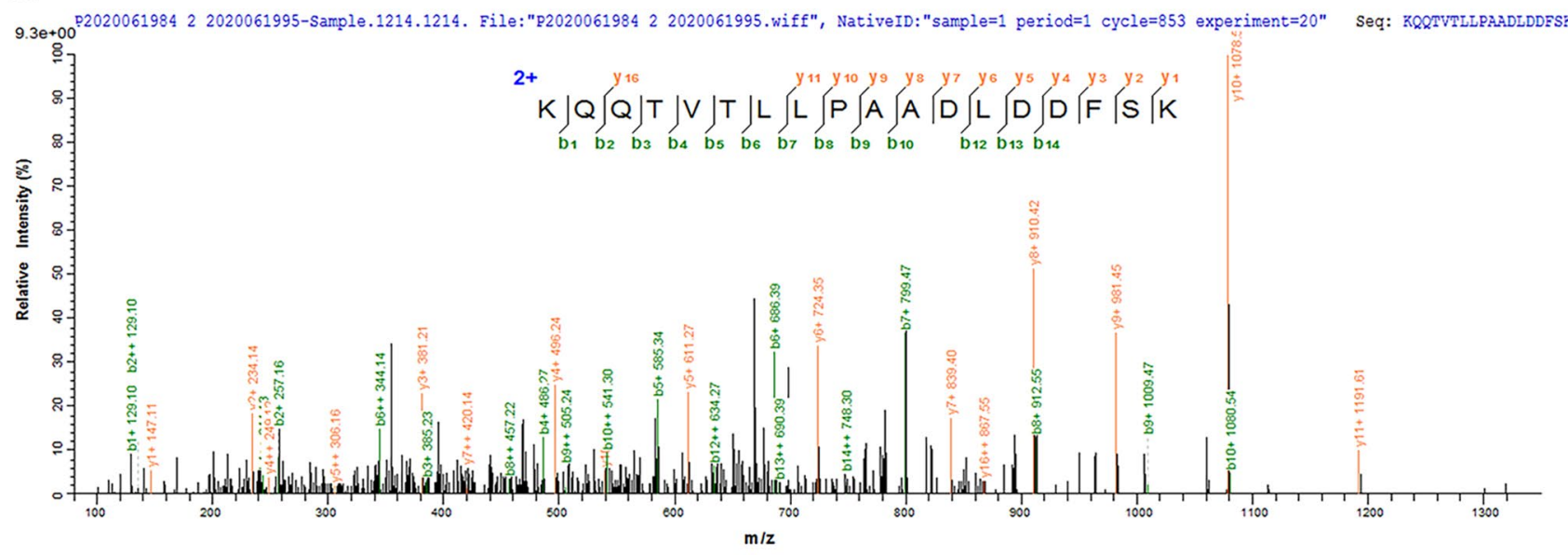

b

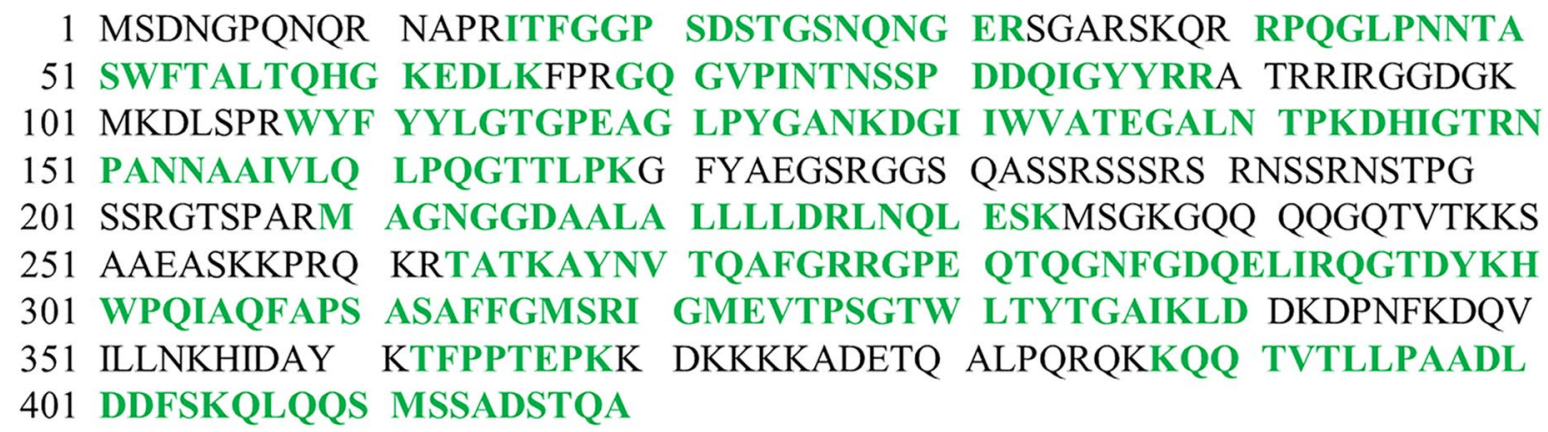

Fig. 3 Mass spectrometric identification of N protein a One of the second order spectrum of the trypsin digestion in the gel band by LC-MSMS of His-fusion $\mathrm{N}$ protein. $\mathbf{b}$ The matched peptide fragments in $\mathrm{N}$ protein. The matched parts are shown in green bold

One of the second-order spectra of trypsin digestion in the gel band was presented (Fig. 3a). The covered portions in $\mathrm{N}$ protein were in bold green (Fig. $3 \mathrm{~b}$ ). The $\mathrm{N}$ protein sequence coverage was about $64 \%$. The above results indubitably confirmed the correct expression of the N-His fusion protein of SARS-CoV-2. 
a

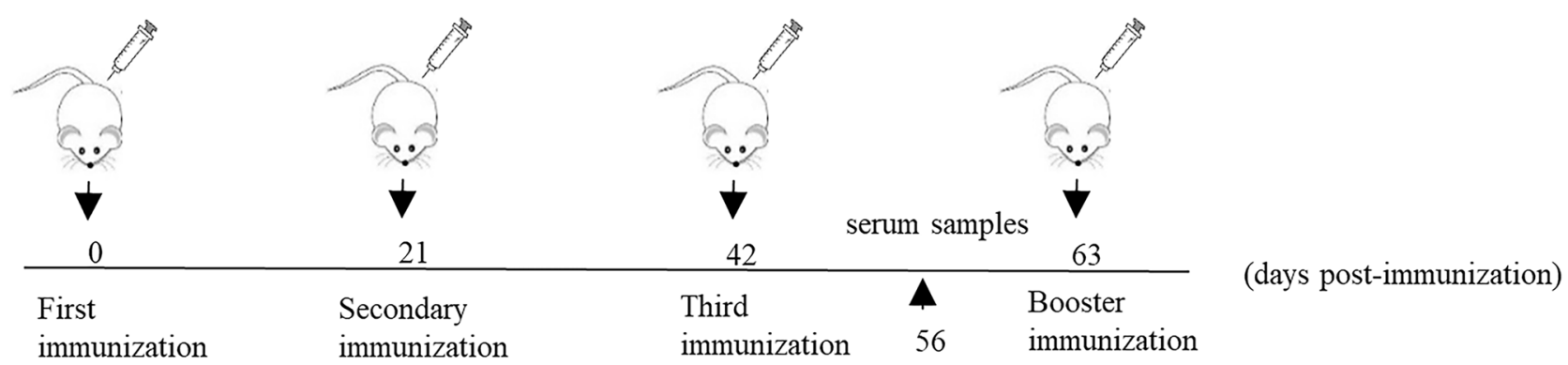

b

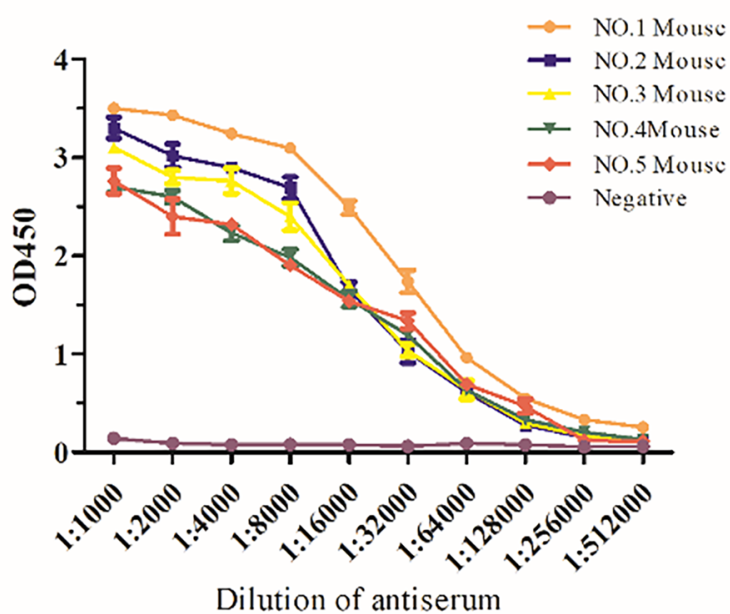

Fig. 4 Determination of titers in mice serum a Immunization program in BALB/C mice. b Titration of $\mathrm{N}$ antibodies in the mice sera 40 days after immunization carried out by ELISA

\section{Preparation and characterization of $\mathbf{m A b s}$ against $\mathbf{N}$ protein}

BALB/C mice were immunized following the program (Fig. 4a); the titers of anti-N antibodies in the serum of tested mice were obviously higher than that from the negative mouse (Table S1). Meanwhile, the result indicated that the antibody titers of NO.1 mouse were higher than those of NO. 2, 3, 4, and 5 mice (Fig. 4b, Table S1). Therefore, the NO.1 mouse was selected for cell fusion. Seven days after cell fusion, the cell clone grew out in the plate and gradually became larger. In this study, we screened six stable positive mAb-secreting hybridoma cell lines and named 4G3, 5B3, 12B6, 18C7-A2, 21H10-A3, and 21H10-E9, respectively.

The results of the indirect ELISA showed that the titers of six mAbs can reach 1:1.3 $\times 10^{7}$ (Fig. 5a). At the same time, the results of the experiment indicated that the isotype of the mAbs were all IgG1/Kappa type (Table 2). Western blot demonstrated that the six mAbs could recognize $\mathrm{N}$ protein of the SARS-CoV-2 and SARS-CoV, but not MERS-CoV (Fig. 5a, b). The $\mathrm{N}$ proteins of SARS-CoV and MERS-CoV were expressed in insect cells (Figure S3). The IFA test further proved the reactivity between the six mAbs and the SARS-CoV-2 N protein (Fig. 5c). From the experimental results, the fluorescence level of the reaction between the monoclonal antibodies and the protein was consistent with that of the positive control (positive serum) and the protein reaction. The above results indicated that the screened six monoclonal antibodies had good reactivity with SARSCoV-2 $\mathrm{N}$ protein. The ELISA was used to analyze the affinity of these mAbs, the high-affinity parameter "Ka" of some mAbs can reach about $4.6 \times 10^{8}$ (Table 2 ). The affinity parameter is calculated according to the following formula (Li et al. 2013 \& Zhou et al. 2009). These results all certified that the mAbs are highly specific to N-His fusion protein.

$$
\begin{gathered}
K a=\frac{\mathrm{n}-1}{2\left(n\left[A b^{\prime}\right] t-[A b] t\right)} \\
n=\frac{[\mathrm{Ag}] \mathrm{t}}{\left[\mathrm{Ag}^{\prime}\right] \mathrm{t}}
\end{gathered}
$$


a
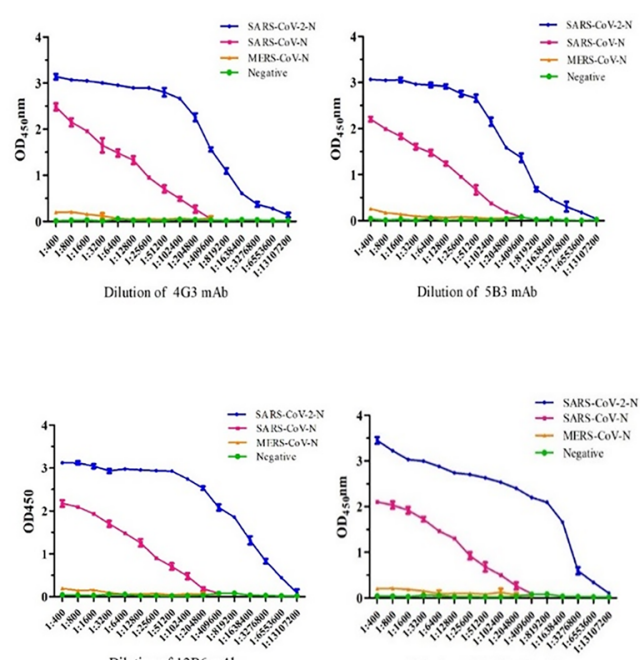

Dilution of $12 \mathrm{~B} 6 \mathrm{mAb}$

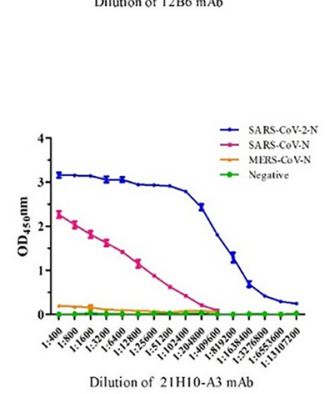

Dilution of $21 \mathrm{H} 10-\mathrm{A} 3 \mathrm{mAb}$

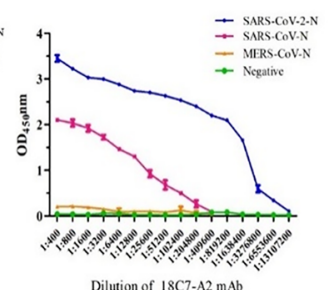

Dilution of $18 \mathrm{C} 7 \cdot \mathrm{A} 2 \mathrm{mAb}$

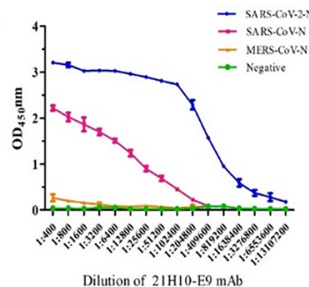

b
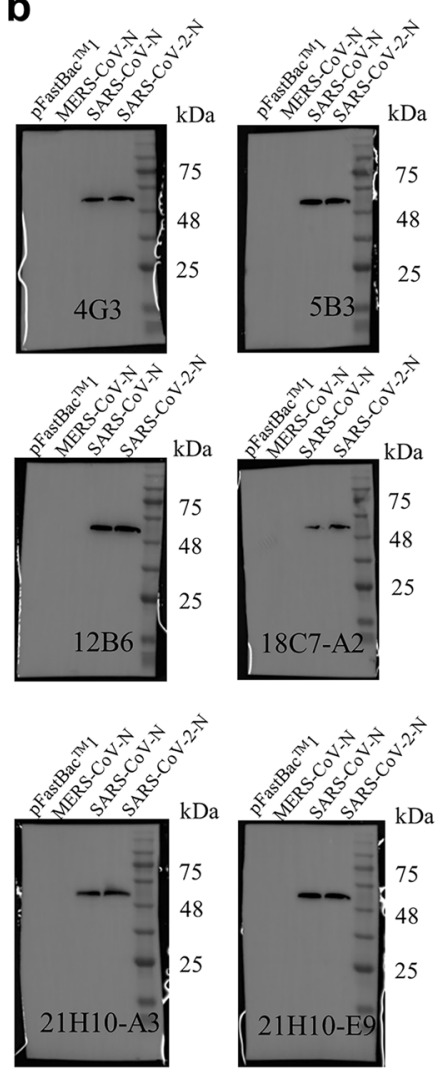

C
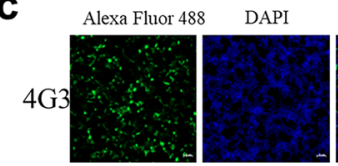

MERGE
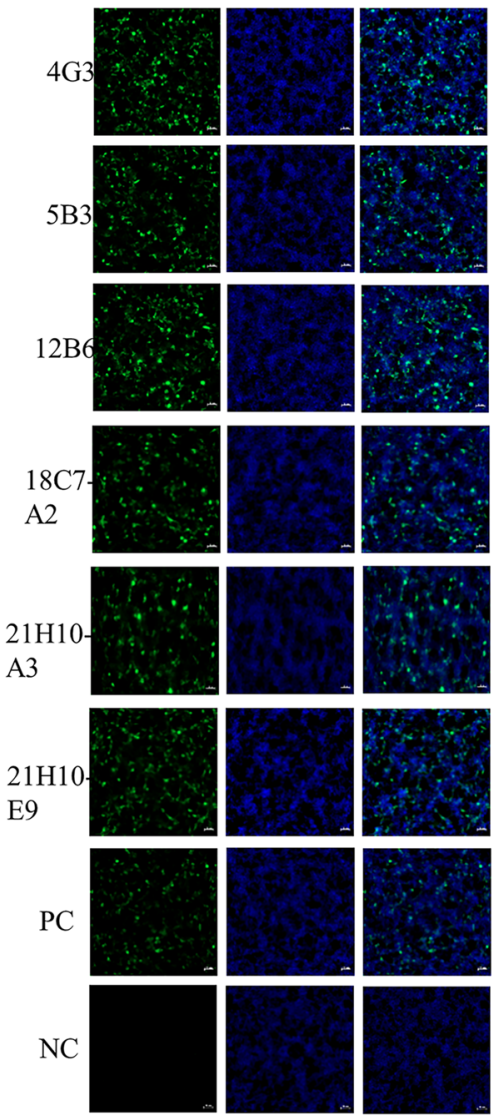

Fig. 5 Characterization of six mAbs prepared using $\mathrm{N}$ protein a Indirect- ELISA was used to analyze binding ability of six mAbs and nucleocapsid protein of SARS-CoV-2, SARS-CoV, and MERS$\mathrm{CoV}$. The negative control (NC) was Baculovirus proteins that pFastBac $^{\mathrm{TM}} 1$ vector transfection with insect sf 21 cells. b Western blot was used to measure the specificity between the six mAbs and SARS-CoV-2 N, SARS-CoV N, and MERS-CoV N protein. The negative control (NC) was Baculovirus proteins that $\mathrm{pFastBac}^{\mathrm{TM}} 1$ vector transfection with insect sf 21 cells. $\mathbf{c}$ IFA assay analyzed the reactivity between six mAbs and SARS-CoV-2 N protein. The green color is anti-N mAbs, the blue color is the nucleus, the negative control (NC) was untransfected pcDNA3.1-N cells and incubated with positive serum; the positive control (PC) was transfected pcDNA3.1-N cells and incubated with positive serum, (the positive serum was eyeball blood from mice that was used to screen for these monoclonal antibodies), Scale bars, $50 \mu \mathrm{m}$
Table 2 Characteristics of $\mathrm{mAbs}$ in this research

\begin{tabular}{llllll}
\hline NO & mAbs & Titers(Ascitic fluid) & \multicolumn{2}{l}{ Types } & \multirow{2}{*}{$\begin{array}{l}\text { Affinity constant } \\
\text { (L/mol) }\end{array}$} \\
& & Heavy chain & Light chain & Kappa & $4.3 \times 10^{8}$ \\
\hline 1 & $4 G 3$ & $1: 6,553,600$ & IgG1 & Kappa & $3.5 \times 10^{6}$ \\
3 & $5 B 3$ & $1: 1,638,400$ & IgG1 & Kappa & $2.1 \times 10^{7}$ \\
4 & $12 B 6$ & $1: 13,107,200$ & IgG1 & Kappa & $3.6 \times 10^{8}$ \\
5 & 18C7-A2 & $1: 1,638,400$ & IgG1 & Kappa & $3.9 \times 10^{8}$ \\
6 & 21H10-A3 & $1: 13,107,200$ & IgG1 & Kappa & $4.6 \times 10^{8}$ \\
\hline
\end{tabular}

$[\mathrm{Ab}$ '] and $[\mathrm{Ab}]$ are the mAb concentrations (ng /L) correspond to $50 \%$ of maximum absorption values of two different concentration plate coating antigens.

$[\mathrm{Ag}] \mathrm{t}$ and $\left[\mathrm{Ag}^{\prime}\right] \mathrm{t}$ represent the molarity of two different coating sources respectively.

\section{Epitope mapping on $\mathrm{N}$ protein recognized by $\mathrm{mAbs}$}

The peptide-ELISA and dot-blot assay were used to determine B cell epitopes of the SARS-CoV-2 N protein. The reaction regions of 14 peptide linear epitopes were measured using the six mAbs. Of the 14 peptides, only N14 


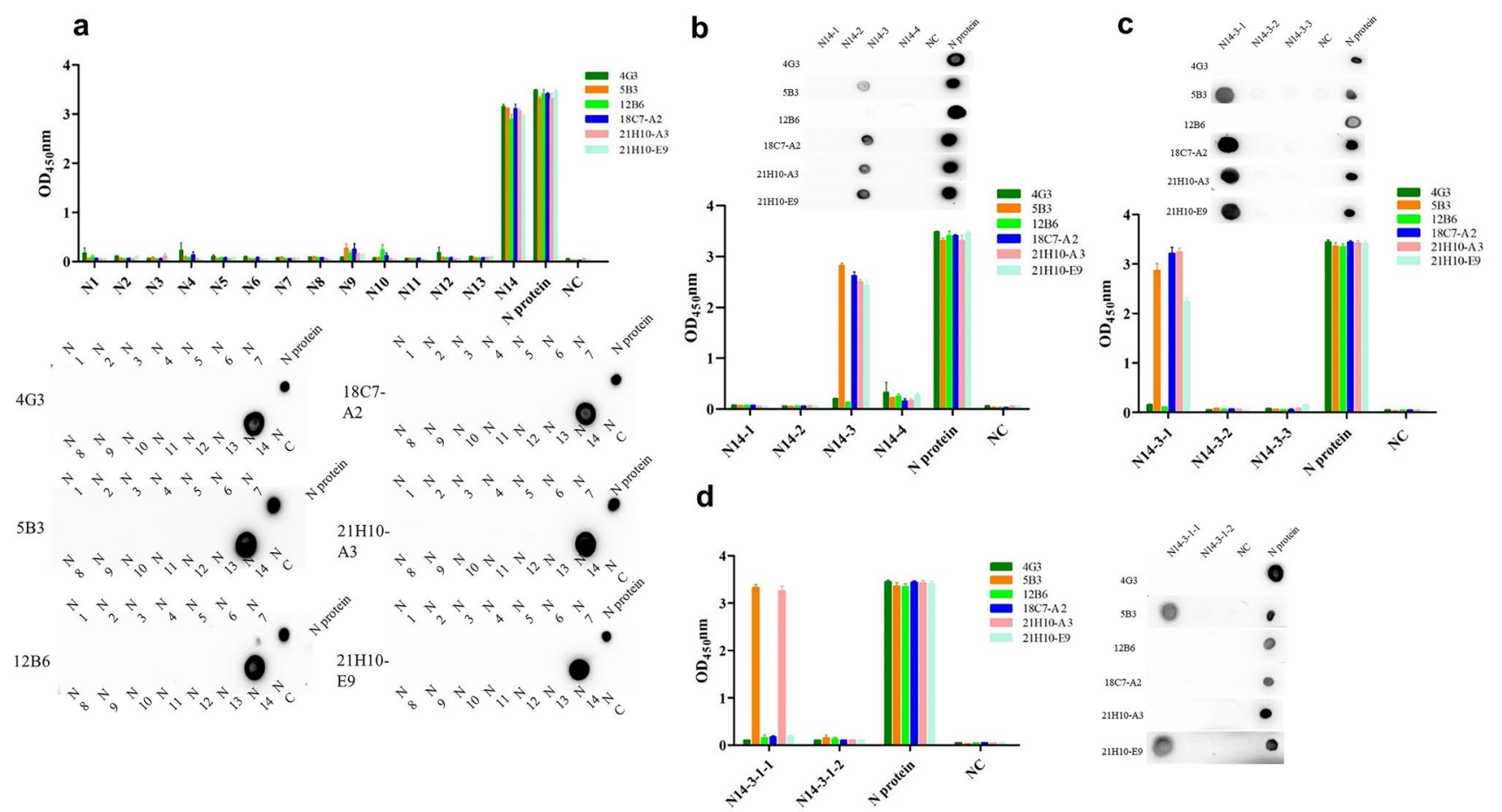

Fig. 6 Map the linear B -cell epitopes of SARS-CoV-2 N protein using the peptide ELISA and Dot -blot assay. The negative control (NC) was BSA protein a Fourteen overlapped peptides (N1-N14) covered intact $\mathrm{N}$ protein were used to bind six mAbs by peptideELISA and dot-blot assay. b The binding of N14-1, N14-2, N14-3,

Table 3 Synthesis protocol of SARS-CoV-2 N protein peptides truncation (Five amino acid residues are repeated between adjacent peptides)

\begin{tabular}{lll}
\hline Peptide ID & Sequence & Location \\
\hline N14-1 & TQALPQRQKKQQTVT & 378-392aa \\
N14-2 & QQTVTLLPAADLDDF & $388-402 \mathrm{aa}$ \\
N14-3 & DLDDFSKQLQQSMSS & $398-412 \mathrm{aa}$ \\
N14-4 & QSMSSADSTQA & $408-418 \mathrm{aa}$ \\
N14-3-1 & DLDDFSKQLQQ & $398-408 \mathrm{aa}$ \\
N14-3-2 & KQLQQSMSSAD & $404-414 \mathrm{aa}$ \\
N14-3-3 & MSSADSTQA & $410-418 \mathrm{aa}$ \\
N14-3-1-1 & DFSKQLQQ & $401-408 \mathrm{aa}$ \\
N14-3-1-2 & SKQLQQ & $403-408 \mathrm{aa}$ \\
\hline
\end{tabular}

peptide (aa 378-418) could be identified by all six mAbs (Fig. 6a). Next, the N14 peptide was further truncated to N14-1, N14-2, N14-3, and N14-4 (Table 3). The binding activity of the four peptides with the six mAbs, upon the peptide-ELISA and dot-blot assay, the N14-3 peptide showed the reaction with the 5B3, 18C7-A2, 21H10-A3, and 21H10-E9 mAbs, but not with 4G3 and 12B6 mAbs (Fig. 6b). The N14-4 had a weak reaction and the N141; N14-2 had no reaction with the six mAbs. To further and N14-4 peptides with six mAbs using the peptide-ELISA and dotblot assay. c The binding of N14-3-1, N14-3-2, N14-3-3 peptides with six mAbs using the peptide-ELISA and dot-blot assay. $\mathbf{d}$ The binding of N14-3-1 and N14-3-1-2 peptides with six mAbs using the peptide-ELISA and dot-blot assay

pinpoint the region of linear B-cell epitopes, we combined N14-3 and N14-4 peptides and truncated it to N14-3-1, N14-3-2, and N14-3-3 (Table 3). Results indicated that the N14-3-1 was shown to bind with the 5B3, 18C7-A2, 21H10-A3, and 21H10-E9 mAbs effectively, but not with the 4G3 and 12B6 mAbs (Fig. 6c). For further mapping the key region, the N14-3-1 peptide was truncated to N143-1-1 and N14-3-1-2 (Table 3). Peptide N14-3-1-1 was shown to bind with $5 \mathrm{~B} 3$ and $21 \mathrm{H} 10-\mathrm{A} 3 \mathrm{mAbs}$, but not with 4G3, 12B6, 18C7-A2, and 21H10-E9 (Fig. 6d). For N143-1-2, all mAbs were shown no reaction with it. To sum up, the 5B3 and 21H10-A3 mAbs can recognize a minimum of eight amino acid epitopes (401-DFSKQLQQ-408), the 18C7-A2 and 21H10-E9 can recognize eleven-amino acid epitopes (398-DLDDFSKQLQQ-408), and the 4G3 and $12 \mathrm{~B} 6$ can map a region of 41 amino acids (378-TQALPQRQKKQQTVTLLPAADLDDFSKQLQQSMSSADSTQA-418).

\section{The conservation of epitopes}

In order to analyze the conservation of linear B-cell epitopes defined by the mAbs prepared in this study, strains from 14 regions in five continents were collected. 
Table 4 The SARS-CoV-2 N protein strains cited in this work

\begin{tabular}{llll}
\hline Name & Accession number & Country & Continent \\
\hline SARS-CoV-2-Hubei-China & YP_009724397 & China & Asia \\
SARS-CoV-2-HongKong-China & QJW69661 & China & Asia \\
SARS-CoV-2-N & QOQ37303 & USA & North America \\
SARS-CoV-2-Japan & BCU66490 & Japan & Asia \\
SARS-CoV-2-Pakistan & QNV71176 & Pakistan & Asia \\
SARS-CoV-2-Sierra & QUX03897 & Sierra Leone & Africa \\
SARS-CoV-2-India & QOS50650 & India & Asia \\
SARS-CoV-2- Italy & QRX3933.1 & Italy & Europe \\
SARS-CoV-2-Austria & QSE38362 & Austria & Europe \\
SARS-CoV-2-New York- USA & QUC93171 & USA & North America \\
SARS-CoV-2-Florida- USA & QTC85863 & USA & North America \\
SARS-CoV-2- Brazil & QVE55309.1 & Brazil & South America \\
SARS-CoV-2-Australia & QPF58246 & Australia & Oceania \\
SARS-CoV -2-Tunisia & QVL01173 & Tunisia & Africa \\
SARS-CoV & AAZ67049.1 & China & Asia \\
MERS-CoV & ATG84884 & Saudi Arabia & Asia \\
\hline
\end{tabular}

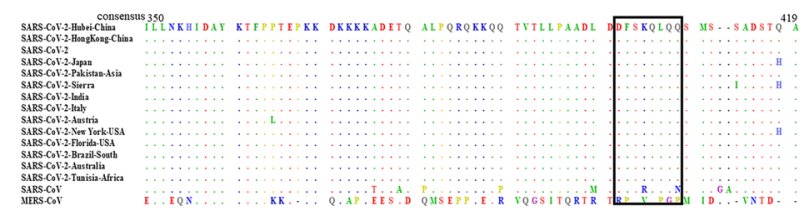

b

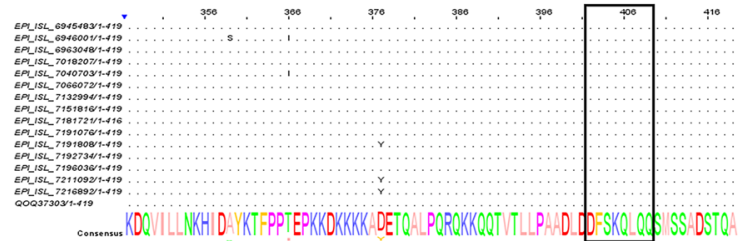

Fig. 7 Bioinformatics analysis of epitopes a Conservation analysis of identified epitopes alignment of SARS-CoV-2 N protein among the different countries, also including SARS-CoV $\mathrm{N}$ and MERS-CoV $\mathrm{N}$ protein expressed in this study. b Analysis of the conservation of epitope according to variants of concern (VOCs) and variants of interest (VOIs) in this work. Accession number was from the GISAID database (https://www.gisaid.org/). The accession number QOQ37303.1 was the SARS-CoV-2 N protein studied in this work. (c) Visualization of the position of the novel lin-

The $\mathrm{N}$ protein sequences of fourteen SARS-CoV-2 strains, SARS-CoV, and MERS-CoV were analyzed together. The detailed information of the $\mathrm{N}$ protein sequences is shown in Table 4 . The alignment analysis found the epitope "401-DFSKQLQQ-408"; even the 41-amino acid epitope region was highly conserved among the

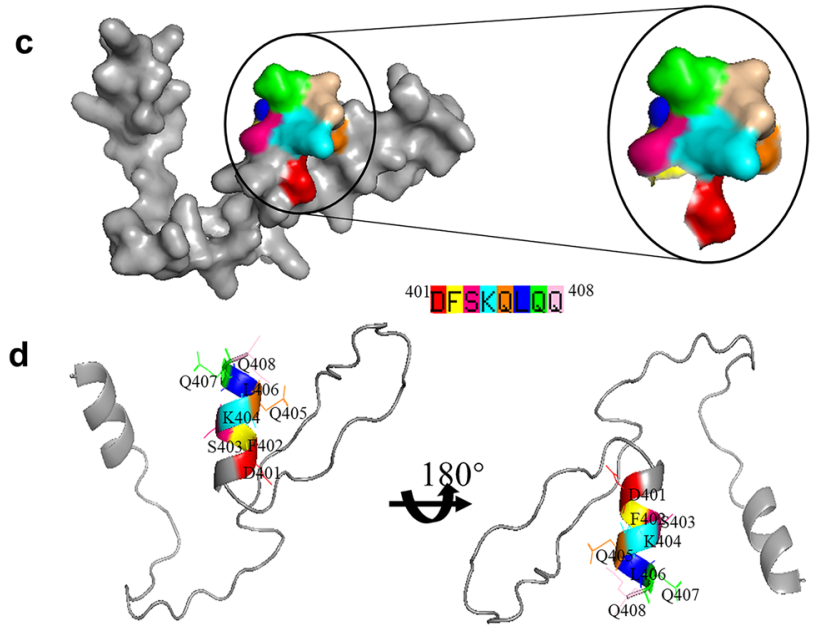

ear B-cell epitope 401-DFSKQLQQ-408 in a spatial structure of $\mathrm{N}$ protein and the alignment modeling sequence of it was from 345 to 419. The 401-DFSKQLQQ-408 epitope was exposed to a $\alpha$-helix (401-DFSKQLQQ-408, labeled color; other amino acids, gray). d The 3D model of $\mathrm{N}$ protein that sequence from 345 to 419 and the spatial position of epitope 401-DFSKQLQQ-408 are shown in the picture (401-DFSKQLQQ-408, labeled color; other amino acids, gray)

strains. The epitope had two amino acids different from the $\mathrm{N}$ protein of SARS-CoV, which was obvious differences with the $\mathrm{N}$ protein of MERS-CoV (Fig. 7a). At the same time, we also analyzed the conservation of epitope according to variants of concern (VOCs) and variants of interest (VOIs); the epitope "401-DFSKQLQQ-408" was 
Table 5 Analysis of the conservation of epitope according to variants of concern (VOCs) and variants of interest (VOIs) in this work. Accession number was from GISAID database (https://www.gisaid. org/)

\begin{tabular}{llll}
\hline Accession number & Pango lineage & WHO label & Country \\
\hline EPI_ISL_7196036 & B.1.1.7 & Alpha & Sweden \\
EPI_ISL_7191076 & B.1.1.7 & Alpha & Japan \\
EPI_ISL_7018207 & B.1.351 & Beta & South Africa \\
EPI_ISL_6963048 & B.1.351 & Beta & Malawi \\
EPI_ISL_7066072 & B.1.351 & Beta & Italy \\
EPI_ISL_7132994 & P.1 & Gamma & Brazil \\
EPI_ISL_7151816 & P.1 & Gamma & Italy \\
EPI_ISL_7216892 & B.1.617.2 & Delta & Sweden \\
EPI_ISL_7211092 & B.1.617.2 & Delta & India \\
EPI_ISL_7181721 & B.1.1.529 & Omicron & UK \\
EPI_ISL_7192734 & B.1.1.529 & Omicron & China, Hong Kong \\
EPI_ISL_6946001 & C.37 & Lambda & Peru \\
EPI_ISL_7040703 & C.37 & Lambda & USA \\
EPI_ISL_7191808 & B.1.621 & Mu & Colombia \\
EPI_ISL_6945483 & B.1.621 & Mu & Colombia \\
\hline
\end{tabular}

also highly conserved among the VOC and VOI strains (Table 5, Fig. 7b).

\section{Three-dimensional visualization of immunogenic epitopes}

The three-dimensional structure of $\mathrm{N}$ protein was built by the SWISS-MODEL server, and the alignment modeling sequence of $\mathrm{N}$ protein was from 345 to 418 . The position of the novel linear B-cell epitope 401-DFSKQLQQ-408 in the spatial structure was visualized by PyMOL software (Fig. 7c). It could be found that the 401-DFSKQLQQ-408 epitope was exposed to the $\alpha$-helix (Fig. 7d) and located on the surface of the protein. This further indicated that the 401-DFSKQLQQ-408 epitope is a linear B-cell epitope.

\section{Discussion}

The rampant behavior of COVID-19 had caused great losses to the global economy, also brought serious threats to human health (Wang et al. 2021). In order to prevent the spread of disease and carry out effective antiviral therapy, a rapid and accurate diagnostic method and reagents for early detection of virus in disease are necessary (Wu et al. 2020b; Chen et al. 2020b). The study showed that the patients who had anti-N protein antibodies account for $89 \%$, while only $63 \%$ of antibodies against $S$ protein in patients (Wang 2020a; Wu et al. 2004b; Zeng et al 2004). The $\mathrm{N}$ protein can react with the sera of most patients, and the sera of patients in the acute phase (5-10 days after virus infection) could not bind with $\mathrm{S}$ protein, but could react with $\mathrm{N}$ protein, which indicates that the anti-N protein antibodies are produced earlier than the anti-S protein antibodies. Moreover, the $\mathrm{N}$ protein of the coronavirus family have high immunogenicity. All these characteristics indicate that $\mathrm{N}$ protein is a preponderant target for diagnosis.

Because of its high specificity and homogeneity, mAbs have been widely used in experimental research and clinical detection (Di et al. 2005). For the preparation of monoclonal antibodies against some special pathogens, the selection of dominant antigen expression products or synthetic peptides as immunogens will undoubtedly bring great convenience (Yamaoka et al. 2016). In this study, the Bac-to-Bac expression system was used to express the codon-optimized $\mathrm{N}$ protein in sf 21 cells. It can promote the correct folding and post-translational modification of the $\mathrm{N}$ protein. In this research, the expression level of $\mathrm{N}$ protein in sf 21 cells was up to $20 \mathrm{mg} / \mathrm{L}$.

Six monoclonal cell lines with high efficiency were prepared and screened using $\mathrm{N}$ protein. The titers of mAbs can reach $1: 1.3 \times 10^{7}$ (Fig. 5a), then they could react with $\mathrm{N}$ protein via IFA assay and western blot experiments (Fig. 5b and c). Interestingly, we found that these monoclonal antibodies could also bind with the $\mathrm{N}$ protein of SARS-CoV, but not with MERS-CoV. It indicates that these monoclonal antibodies could be served to assay SARS-CoV-2 and SARS-CoV simultaneously. We performed multiple sequence alignments of epitopes recognized by monoclonal antibodies and found that SARS-CoV N protein differed only at 404 position " $K$ " to " $R$ " and 408 position "Q" to "N" in "DFSKQLQQ" from 401-408. To some extent, the monoclonal antibodies prepared in this study were shown certain advantages, which can detect both SARS-CoV-2 and SARS-CoV. Preparation and characterization of six mAbs provide new experimental material for the detection of SARS-CoV-2 and SARS-CoV.

Epitopes are the basis of protein antigenicity, and they act a vital part in the preparation of specific antibodies against proteins, the computer-aided design of vaccines, especially in the recent tumor immunotherapy (Corral-Lugo et al. 2020). Epitopes are divided into linear epitopes and conformational epitopes. According to the amino acid sequence of antigenic protein, a series of peptide fragments of multiple overlapping amino acids are synthesized, and the peptide segments that can be recognized by $\mathrm{B}$ cells are determined by antibody binding test. It is the most classic method of B-cell epitope screening, which can accurately and effectively detect linear B-cell epitopes. According to this study, 14 overlapped peptides were synthesized according to the $\mathrm{N}$ protein sequence of SARS-CoV-2, and peptide N14 was screened out using the monoclonal antibodies prepared in this study (Fig. 6). The N14 peptide was progressively 
truncated and finally fine mapped to 401-DFSKQLQQ-408 (Fig. 6) as a novel linear B-cell epitope.

At present, there are few reports on B-cell epitopes of $\mathrm{N}$ protein in SARS-CoV-2. Sergio C. Oliveria reported that the most dominant $\mathrm{B}$-cell epitopes of $\mathrm{N}$ protein in SARS-CoV-2 are located between aa176 and 206 (Rakib et al. 2020). Yufeng Dai predicted the immunodominant epitopes of $\mathrm{N}$ protein using several bioinformatics servers, including N229-269, N349-399, and N405-419 (Dai et al. 2020). Terry et al. reported the preparation of the monoclonal antibody that recognizes amino acids at position 381-419 aa of N protein (Terry et al. 2021). Amrun et al. found that the positive serum of patients could recognize the amino acid site 153-170 of N protein (Amrun et al. 2020). Tian et al. mapped the epitope using a Rabbit $\mathrm{mAb}$ (Tian et al. 2021). In this paper, a novel linear B-cell epitope 401-DFSKQLQQ-408 of N protein was identified by $5 \mathrm{~B} 3$ and $21 \mathrm{H} 10-\mathrm{A} 3 \mathrm{mAbs}$ for the first time. The six mAbs all can map the epitope region 378-418aa (Fig. 6a). Interestingly, all the six mAbs could bind the epitope region 378-418aa, 4G3, and 12B6 mAbs could not bind the truncated epitope, while 5B3, 18C-A2, 21H10A3, and 21H10-E9 mAbs could (Fig. 6b, c). The epitope was further truncated to eight-amino acids (401-408 aa), and only $5 \mathrm{~B} 3$ and $21 \mathrm{H} 10-\mathrm{A} 3 \mathrm{mAbs}$ could recognize it, but not for 18C7-A3 and 21H10-E9 mAbs (Fig. 6d). Namely, the monoclonal antibodies prepared in this work could recognize epitope regions of different lengths. Meanwhile, compared with the sequences of SARS-CoV-2 N from five continents including 14 regions, the peptide 401-DFSKQLQQ-408 was highly conserved (Fig. 7).

In conclusion, $\mathrm{N}$ protein of SARS-CoV-2 was expressed and purified in insect sf 21 cells via the Bac-to-Bac expression system. Six anti-N monoclonal antibodies were prepared and characterized. A novel linear B -cell epitope 401-DFSKQLQQ-408 of N protein was identified for the first time, which was highly conserved in strains from different countries and VOC's and VOI's strains. The findings of this study provide new thoughts for the diagnosis and test target of COVID-19 and the design of the vaccine.

Supplementary Information The online version contains supplementary material available at https://doi.org/10.1007/s00253-022-11769-6.

Acknowledgements We are grateful for the support of the General Program of National Natural Science Foundation of China (2020 Fund Project, grant number 32072944 ) and "Collaborative Innovation Major Project of Zhengzhou, Henan in 2020". We thank the master Siyuan Liu of Henan Agricultural University for the help in animal experiments.

Author contribution YT, GZ, and AW designed the research and analyzed the data. HL, PD, JZ, RJ, and YC performed the statistical analysis. YT, YQ, JD, CL, and XZ performed the experiments. YT wrote the first draft of the manuscript. YT, AW, and GZ contributed to manuscript revision, read, and approved the submitted version.

Funding This study was mainly supported by the General Program of National Natural Science Foundation of China (2020 Fund Project, grant number 32072944) and "Collaborative Innovation Major Project of Zhengzhou, Henan in 2020."

Data availability statements The data that support for the findings of this study are all contained in the manuscript and supplement materials.

Code availability Not applicable for that section.

\section{Declarations}

Ethics approval All animals were cared for in a sterile environment and fed ad freely. The procedures for care and use of animals have been approved by the Ethics and Animal Welfare Committee of Henan Academy of Agricultural Sciences (Approval number LLSC410028), and the applicable institutions and government regulations regarding the ethical use of animals have been complied with.

Conflict of interest The authors declare no competing interests.

\section{References}

Amrun SN, Lee CYP, Lee B, Fong SW, Young BE, Chee RSL, Yeo NKW, Ruesta ATR, Carissimo G, Poh CM, Chang ZW, Tay MZ, Chan YH, Chen MIC, Low JGH, Tambyah PA, Kalimuddin S, Pada S, Tan SY, Sun LJ, Leo YS, Lye DC, Renia L, Ng LFP (2020) Linear B-cell epitopes in the spike and nucleocapsid proteins as markers of SARS-CoV-2 exposure and disease severity. EBioMedicine 58:102911. https://doi.org/10.1016/j.ebiom.2020. 102911

Burbelo PD, Riedo FX, Morishima C, Rawlings S, Smith D, Das S, Strich JR, Chertow DS, Davey RT, Cohen JI (2020) Sensitivity in detection of antibodies to nucleocapsid and spike proteins of severe acute respiratory syndrome coronavirus 2 in patients with coronavirus disease 2019. J Infect Dis 222(2):206-213. https:// doi.org/10.1093/infdis/jiaa273

Chan JFW, Yuan SF, Kok KH, To KKW, Chu H, Yang J, Xing FF, Liu JL, Yip CCY, Poon RWS, Tsoi HW, Lo SKF, Chan KH, Poon VKM, Chan WMC, Daniel J, Cai JP, Cheng VCC, Chen HL, Hui CKM, Yuen KY (2020) A familial cluster of pneumonia associated with the 2019 novel coronavirus indicating person-to-person transmission: a study of a family cluster. Lancet 395:514-523. https://doi.org/10.1016/S0140-6736(20)30154-9

Chen ZW, Ruan PL, Wang LL, Nie XM, Ma XJ, Tan YR (2020a) T and $B$ cell Epitope analysis of SARS-CoV-2 S protein based on immunoinformatics and experimental research. J Cell Mol Med 00:1-16. https://doi.org/10.1111/jcmm.16200

Chen ZQ, Wu QH, Chen J, Ning XH, Dai JF (2020b) A DNA aptamer based method for detection of SARS-CoV-2 nucleocapsid protein. Virol Sin 35:351-354. https://doi.org/10.1007/ s12250-020-00236-Z

Dai YF, Chen HZ, Zhuang SQ, Feng XJ, Fang YY, Tang HN, Dai RC, Tang LL, Liu J, Ma TM, Zhong GM (2020) Immunodominant regions prediction of nucleocapsid protein for SARS-CoV-2 early diagnosis: a bioinformatics and immunoinformatics study. Pathog Glob Health 14(8):463-470. https://doi.org/10.1080/20477724. 2020.1838190 
de Groot RJ, Baker SC, Baric R, Enjuanes L, Gorbalenya AE (2012) Family Coronaviridae. In: King AMQ, Adams MJ, Carstens EB, Lefkowitz EJ. Virus taxonomy: classification and nomenclature of viruses: ninth report of the International Committee on Taxonomy of Viruses. London; Waltham: Academic Press

Di B, Hao W, Gao Y, Wang M, Wang YD, Qiu LW, Wen K, Zhou DH, Wu XW, Lu EJ, Liao ZY, Mei YB, Zheng BJ, Che XY (2005) Monoclonal antibody-based antigen capture enzyme-linked immunosorbent assay reveals high sensitivity of the nucleocapsid protein in acute-phase sera of severe respiratory syndrome patients. Clin Diagn Lab Immunol 12(1):135-140. https://doi.org/ 10.1128/CDLI.12.1.135-140.2005

Egger M, Bundschuh C, Wiesinger K, Gabriel C, Clodi M, Mueller T, Dieplinger B (2020) Comparison of the Elecsys Anti-SARSCoV-2 immunoassay with the EDITM enzyme linked immunosorbent assays for the detection of SARS-CoV-2 antibodies in human plasma. Clin Chim Acta 509:18-21. https://doi.org/10. 1016/j.cca.2020.05.049

Gorbalenya AE, Baker SC, Baric RS, de Groot RJ, Drosten C, Gulyaeva AA, Haagmans BL, Lauber C, Leontovich AM, Neuman BW, Penzar D, Perlman S, Poon LLM, Samborskiy DV, Sidorov LA, Sola L, Ziebuhr J (2020) The species severe acute respiratory syndrome-related coronavirus: classifying 2019-nCoV and naming it SARS-CoV-2. Nat Microbiol 5:536-544. https://doi.org/10. 1038/s41564-020-0695-Z

Huang CL, Wang YM, Li XW, Ren LL, Zhao JP, Hu Y, Zhang L, Fan GH, Xu JY, Gu XY, Cheng ZS, Yu T, Xia JN, Wei Y, Wu WJ, Xie XL, Yin W, Li H, Liu M, Xiao Y, Gao H, Guo L, Xie JG, Wang GF, Jiang RM, Gao ZC, Jin Q, Wang JW, Cao B (2020) Clinical features of patients infected with 2019 novel coronavirus in Wuhan, China. Lancet 395:497-506. https://doi.org/10. 1016/S0140-6736(20)30183-5

Huang R, Xia J, Chen YX, Shan C, Wu C (2020b) A family cluster of SARS-CoV-2 infection involving 11 patients in Nanjing, China. Lancet Infect Dis 20:534-535. https://doi.org/10.1016/S14733099(20)30147-X

Hu ZL, Song C, Xu CJ, Jin GF, Chen YL, Xu X, Ma HX, Chen WL, Lin Y, Zheng YS, Wang JM, Hu ZB, Yi YX, Shen HB (2020) Clinical characteristics of 24 asymptomatic infections with COVID-19 screened among close contacts in Nanjing, China. Sci China Life Sci 63:706-711. https://doi.org/10.1007/ s11427-020-1661-4

Jiang M, Guo JQ, Zhang GP, Jin QY, Liu YK, Jia R, Wang AP (2020) Fine mapping of linear $\mathrm{B}$ cell epitopes on capsid protein of porcine circovirus 3. Appl Microbiol Biotechnol. https://doi.org/10. 1007/s00253-020-10664-2

Kang SS, Yang M, Hong ZS, Zhang LP, Huang ZX, Chen XX, He SS, Zhou ZL, Zhou ZC, Chen QY, Yan Y, Zhang CS, Shan H, Chen SD (2020) Crystal structure of SARS-CoV-2 nucleocapsid protein RNA binding domain reveals potential unique drug targeting sites. Acta Pharm Sin B 10(7):1228-1238. https://doi.org/10. 1016/j.apsb.2020.04.009

Li L, Zhou Y, Li YS, Feng XL, Song J, Liu YY, Gao SQ, Zhang YY, Li ZH, Wang GM, Tang F, Lu SY, Li ZH, Ren HL (2013) Preparation of an antigen and development of a monoclonal antibody against mono-butylphthalate (MBP). Food Agric Immunol 24(2):193202. https://doi.org/10.1080/09540105.2012.677010

Li ST, Lin L, Wang H, Yin JN, Ren Y, Zhao Z, Wen J, Zhou CQ, Zhang XM, Li XL, Wang JQ, Zhou ZF, Liu JX, Shao JM, Lei TT, Fang JQ, Xu NZ, Liu SQ (2003) The epitope study on the SARS-CoV nucleocapsid protein. Genom Proteom Bioinform 1:198-206. https://doi.org/10.1016/S1672-0229(03)01025-8

Liu K, Fang YY, Deng Y, Liu W, Wang MF, Ma JP, Xiao W, Wang YN, Zhong MH, Li CH, Li GC, Liu HG (2020) Clinical characteristics of novel coronavirus cases in tertiary hospitals in Hubei Province.
Chin Med J 133:1025-1031. https://doi.org/10.1097/CM9.00000 00000000744

Lugo CA, Siles ML, López D, McConnell M, Galiano AJM (2020) Identification and analysis of unstructured, linear B-cell epitopes in SARS-CoV-2 virion proteins for vaccine development. Vaccines (basel) 8(3):397. https://doi.org/10.3390/vaccines8030397

Luo YY, Guo XL, Yan HJ, Fang DY, Zeng GC, Zhou JM, Jiang LF (2015) Comprehensive mapping infection-enhancing epitopes of dengue pr protein using polyclonal antibody against prM. Appl Microbiol Biotechnol 99:5917-5927. https://doi.org/10.1007/ s00253-015-6538-9

Oliveria SC, Magalhaes M, Homan EJ (2020) Immunoinformatic analysis of SARS-CoV-2 nucleocapsid protein and identification of COVID-19 vaccine targets. Front Immunol 11. https://doi.org/ 10.3389/fimmu.2020.587615

Rakib A, Sami SA, Islam MA, Ahmed S, Faiz FB, Khanam BH, Marma KKS, Rahman M, Gandara JS (2020) Epitope-based immunoinformatics approach on nucleocapsid protein of severe acute respiratory syndrome-coronavirus-2. Molecules 25(21):5088. https:// doi.org/10.3390/molecules25215088

Snijder EJ, Bredenbeek PJ, Dobbe JC, Thiel V, Ziebuhr J, Poon LLM, Guan Y, Rozanov M, Spaan WJM, Gorbalenya AE (2003) Unique and conserved features of genome and proteome of SARS-coronavirus, an early split-off from the coronavirus group 2 lineage. J Mol Biol 331:991-1004. https://doi.org/10.1016/S0022-2836(03) 00865-9

Stertz S, Reichelt M, Spiegel M, Kuri T, Martinez-Sobrido L, Garcia-Sastre A, Weber F, Kochs G (2006) The intracellular sites of early replication and budding of SARS-coronavirus. Virology 361(2):304-315. https://doi.org/10.1016/j.virol.2006.11.027

Terry JS, Anderson LBR, Scherman MS, McAlister CE, Perera R, Schountz T, Geiss BJ (2021) Development of a SARS-CoV-2 nucleocapsid specific monoclonal antibody. Virology 558 (10):28-37. https://doi.org/10.1016/j.virol.2021.01.003

Tian XG, Mo CC, Zhou LL, Yang YJ, Zhou ZC, You AP, Fan Y, Liu WK, Li X, Zhou R (2021) Epitope mapping of severe acute respiratory syndrome-related coronavirus nucleocapsid protein with a rabbit monoclonal antibody. Virus Res 300(971-977):198445. https://doi.org/10.1016/j.virusres.2021.198445

Tilocca B, Soggiu A, Sanguinetti M, Musella V, Britti D, Bonizzi L, Urbani A, Roncada P (2020) Comparative computational analysis of SARS-CoV-2 nucleocapsid protein epitopes in taxonomically related coronaviruses. Microbes Infect 22(4-5):188-194. https:// doi.org/10.1016/j.micinf.2020.04.002

Wang AP, Jiang M, Liu HL, Liu YK, Zhou JM, Chen YM, Ding PY, Wang YW, Pang WS, Qi YH, Zhang GP (2021) Development and characterization of monoclonal antibodies against the $\mathrm{N}$-terminal domain of African swine fever virus structural protein, p54. Int J Biol Macromol 180:203-211. https://doi.org/10.1016/j.ijbiomac. 2021.03.059

Wang P (2020a) Combination of serological total antibody and RTPCR test for detection of SARS-CoV-2 infections. J Virol Methods 283. https://doi.org/10.1016/j.jviromet.2020.113919

Wang X, Zhang JL, Huo SS, Zhang YH, Wu FY, Cui D, Yu HW, Zhong F (2020b) Development of a monoclonal antibody against canine parvovirus NS1 protein and investigation of NS1 dynamics and localization in CPV-infected cells. Protein Expr Purif 174:105682. https://doi.org/10.1016/j.pep.2020.105682

Wu F, Zhao S, Yu B, Chen YM, Wang W, Song ZG, Hu Y, Tao ZW, Tian JH, Pei YY, Yuan ML, Zhang YL, Dai FH, Liu F, Wang QM, Zheng JJ, Xu L, Holmes EC, Zhang YZ (2020a) A new coronavirus associated with human respiratory disease in China. Nature 579(7798):1-8. https://doi.org/10.1038/s41586-020-2008-3

Wu HS, Hsieh YC, Su IJ, Lin TH, Chiu SC, Hsu YF, Lin JH, Wang MC, Chen JY, Hsian PW, Chang GD, Wang AHJ, Ting HW, Chou CM, Huang CJ (2004) Early detection of antibodies against 
various structural proteins of the SARS-associated coronavirus in SARS patients. J Biomed Sci 11:117-126. https://doi.org/10. $1159 / 000075294$

Wu XD, Shang B, Yang RF, Yu H, Ma ZH, Shen X, Ji YY, Li Y, Wu YD, Lin GM, Tian L, Gan XQ, Yang S, Jiang WH, Dai EH, Wang XY, Jiang HL, Xie YH, Zhu XL, Pei G, Wu RJ, Sun B (2004b) The spike protein of severe acute respiratory syndrome (SARS) is cleaved in virus infected Vero-E6 cells. Cell Res 14:400-406. https://doi.org/10.1038/sj.cr.7290240

Wu YT, Ho WZ, Huang YW, Jin DY, Li SY, Liu SL, Liu SF, Qiu JM, Sang YM, Wang QH, Yuen KY, Zheng ZM (2020b) SARS$\mathrm{CoV}-2$ is an appropriate name for the new coronavirus. Lancet 395:949-950. https://doi.org/10.1016/S0140-6736(20)30557-2

Xie CJ, Wang RZ, Saeed AFUH, Yang QH, Chen HL, Xiao SW, Zeng LM, Wang SH (2018) Preparation of anti-Human podoplanin monoclonal antibody and its application in immunohistochemical diagnosis. Sci Rep 8:10162-10172. https://doi.org/10.1038/ s41598-018-28549-w

Yamaoka1 Y, Matsuyama S, Fukushi S, Matsunaga S, Matsushima Y, Kuroyama H, Kimura H, Takeda M, Chimuro T, Ryo A (2016) Development of monoclonal antibody and diagnostic test for middle east respiratory syndrom coronavirus using cell-free synthesized nucleocapsid antigen. Front Microbiol 7 (509). https://doi. org/10.3389/fmicb.2016.00509

Zeng R, Ruan HQ, Jiang XS, Zhou H, Shi L, Zhang L, Sheng QH, Tu Q, Xia QC, Wu JR (2004) Proteomic analysis of SARS associated coronavirus using two-dimensional liquid chromatography mass spectrometry and one-dimensional sodium dodecyl sulfatepolyacrylamide gel electrophoresis followed by mass spectrometric analysis. J Proteome Res 3:549-555. https://doi.org/10.1021/ $\operatorname{pr} 034111 \mathrm{j}$

Zhang J, Wang D, Li Y, Zhao Q, Huang AL, Zheng J, Chen WX (2011) SARS coronavirus nucleocapsid protein monoclonal antibodies developed using a prokaryotic expressed protein. Hybridoma 30(5):481. https://doi.org/10.1089/hyb.2011.0028
Zhao X, Nicholls J, Chen Y (2008) Severe acute respiratory syndromeassociated coronavirus nucleocapsid protein interacts with $\mathrm{Smad} 3$ and modulates transforming growth factor- $\beta$ signaling. J Biol Chem 283(6):3272-3280. https://doi.org/10.1074/jbc.M7080 33200

Zhou Y, Li YS, Pan FG, Zhang YY, Lu SY, Ren HL, Li ZH, Liu ZS, Zhang JH (2009) Development of a new monoclonal antibody based direct competitive enzyme-linked immunosorbent assay for detection of brevetoxins in food samples. Food Chem 118:467471. https://doi.org/10.1016/j.foodchem.2009.05.015

Zhou P, Yang XL, Wang XG, Hu B, Zhang L, Zhang W, Si HR, Zhu Y, Li B, Huang CL, Chen HD, Chen J, Luo Y, Guo H, Jiang RD, Liu MQ, Chen Y, Shen XR, Wang X, Zheng XS, Zhao K, Chen QJ, Deng F, Liu LL, Yan B, Zhan FX, Wang YY, Xiao GF, Shi ZL (2020) A pneumonia outbreak associated with a new coronavirus of probable bat origin. Nature 579:270-273. https://doi.org/10. 1038/s41586-020-2012-7

Zhu GL, Zhu CM, Zhu Y, Sun F (2020a) Mini review of progress in the structural study of SARS-CoV-2 proteins. Curr Res Microb Sci 1:53-61. https://doi.org/10.1016/j.crmicr.2020.06.003

Zhu N, Zhang DY, Wang WL, Li XW, Yang B, Song JD, Zhao X, Huang B, Shi WF, Lu RJ, Niu PH, Zhan FX, Ma XJ, Wang DY, Xu WB, Wu GZ, Gap GF, Tan WJ (2020b) A novel coronavirus from patients with pneumonia in China, 2019. N Engl J Med 382:727-733. https://doi.org/10.1056/NEJMoa2001017

Publisher's note Springer Nature remains neutral with regard to jurisdictional claims in published maps and institutional affiliations. 